IGA PĘKALA

Instytut Dziennikarstwa i Komunikacji Społecznej Uniwersytet Wrocławski

\section{Przestrzeń poza kadrem - o sensualnym wymiarze zdjęć filmowych Emmanuela Lubezkiego}

\begin{abstract}
Pękala Iga, Przestrzeń poza kadrem - o sensualnym wymiarze zdjęć filmowych Emmanuela Lubezkiego [The space outside the frame - about the sensual dimension of film shots by Emmanuel Lubezki]. "Images" vol. XXVII, no. 36. Poznań 2020. Adam Mickiewicz University Press. Pp. 143-155. ISSN 1731-450X. DOI 10.14746/i.2020.36.09.

The article presents an analysis of the sensual potential of film images via the example of cooperation between operator Emmanuel Lubezki and three directors: Alejandro Gonzales Iñárritu, Alfonso Cuarón and Terrence Malick. The impact of reconstruction of film space on the sensual impressions of viewers in the context of the American theory of somatic cinema was also analyzed. What influence does the dimension of cinematographic cooperation have on the concept of authorial cinema?

KEYWORDS: film space, means of film expression, sensual theory of cinema, Emmanuel Lubezki, Alejandro Gonzales Iñárritu, Alfonso Cuarón, Terrence Malick
\end{abstract}

Filmowe światy to przede wszystkim ruchome obrazy. Emmanuel Lubezki kreuje nowe rzeczywistości we współpracy z wieloma twórcami, których moglibyśmy nazwać autorami filmowymi. W jaki sposób w tym kontekście funkcjonuje relacja sztuki operatorskiej i kina autorskiego? Jaki wpływ wywiera styl zdjęć filmowych Emmanuela Lubezkiego na twórczość trójki reżyserów: Alfonsa Cuaróna, Alejandra Gonzalesa Iñárritu, Terrence’a Fredericka Malicka? Chciałabym zastanowić się nad tym na wybranych przykładach - między innymi na podstawie Ludzkich dzieci (Children of Men, reż. A. Cuarón, 2006), Zjawy (The Revenant, reż. A.G. Iñárritu, 2015) i Drzewa życia (The Tree of Life, reż. T. Malick, 2011).

Kolejnym podjętym zagadnieniem będzie zmysłowy potencjał płynący ze zdjęć filmowych. Punkt wyjścia dla analizy charakteru takiego oddziaływania stanowi zmysłowa teoria kina - szczególnie w perspektywie sensualnych wrażeń płynących już z samych środków filmowego wyrazu, które mogą pociągać za sobą cielesne reakcje u widzów. Puls przyśpiesza, ciało drży, skóra reaguje na zapamiętane wcześniej wrażenia. Przedstawiciele amerykańskiej teorii kina somatycznego wskazują na całościowość filmowego doświadczenia, zwracającego się w stronę ciała, zmysłów i intelektualnego odbioru danych zbieranych zarówno ze strony formalnej, jak i z warstwy treściowej.

W artykule zostanie przeanalizowany zmysłowy potencjał zdjęć filmowych. Pojedynczy kadr może być traktowany jako rodzaj obrazu, warto zatem skierować się w stronę teorii sztuki. Zmysłowość filmowe-
Images

vol. XXVII/no. 36

Poznań 2020

ISSN 1731-450X
Zmysłowa teoria kina a sztuka operatorska 
go dzieła może być związana z układem kadru, oświetleniem, zwróceniem uwagi na spojrzenia wymieniane pomiędzy bohaterami. Sztuka operatorska pociąga za sobą również kreację filmowej przestrzeni, która nie pozostaje obojętna dla percepcji widzów.

Przestrzeń filmowa wiąże się z połączeniem intelektualnej analizy i zmysłowych, podświadomych wrażeń. W dużej mierze konstruujemy ją sami i jest ona większa niż pokazana na ekranie. Całość filmowej przestrzeni możemy wychwytywać na przykład z dźwięków dobiegających spoza obrębu kadru. Aby spróbować przeanalizować sensualny potencjał zdjęć filmowych, warto zacząć od zmysłowej teorii kina, w świetle której odbieramy dzieła filmowe wielowymiarowo cieleśnie i zmysłowo.

Niełatwo sprecyzować, kiedy dokładnie nastąpił zmysłowy zwrot filmowej teorii. Można wskazywać na konkretyzację tego nurtu w amerykańskiej teorii kina somatycznego. Jej najwybitniejszymi przedstawicielami są: Laura U. Marks, Vivian Sobchack, Allen Casebier i Steven Shaviro. Sensuous theory to teoria łącząca w postrzeganiu dzieła filmowego wartości estetyczne i potencjał zmysłowy. Vivian Sobchack „traktuje doświadczenie filmowe jako system komunikacji oparty na cielesnej percepcji”[1]. Dzieło filmowe jest ujmowane w tym kontekście jako komunikat - należy zatem zapytać, co przekazuje. Mogłyby to być zarówno informacje, emocje, jak i wrażenia.

Myślenie o kinie w kontekście zmysłowego odbioru pojawiło się jednak już wcześniej. Pewne przejawy tego nurtu możemy dostrzec w Teorii filmu. Wyzwoleniu materialnej rzeczywistości Siegfrieda Kracauera, zaś inspiracją dla sensuous theory może być Fenomenologia percepcji Maurice'a Merleau-Ponty’ego. Nie sposób nie wspomnieć także o publikacji Teoria filmu: wprowadzenie przez zmysty autorstwa Thomasa Elsaessera i Malte Hagenera, która stanowi zbiór wykładów poświęconych zmysłowemu oddziaływaniu filmu.

Kolejnym aspektem zmysłowego zwrotu w myśleniu o filmie byłoby zwrócenie uwagi przez Laurę U. Marks na pojęcie haptyczności, w świetle którego nasz mózg zapamiętuje wrażenia dotykowe i może odtworzyć je później za pomocą zmysłu wzroku. Badaczka postuluje, że film można badać jak realną strukturę, niemalże dotknąć jej faktury, kształtów i wypukłości, które wywołują w widzu rodzaj afektywnego rezonansu. Twierdziła także, że w kontakcie $\mathrm{z}$ kinem rozpuszczamy swoją podmiotowość w bliskim i cielesnym kontakcie z obrazem. W swojej publikacji The Skin of the Film autorka rozważa perspektywę ucieleśnionego doświadczenia, które ma społeczny i kulturowy, ale już niekoniecznie indywidualny charakter. Wydaje się, że w tej perspektywie kinowa percepcja ma wymiar intersubiektywny - cielesne reakcje stanowią element wspólnego doświadczenia. Podstawowym założeniem

[1] V. Sobchack, Pieprzyć ciało/ przetrzymać tekst, czyli jak wyjść cało z tego stulecia, przeł. M. Szcześniak i Ł. Zaremba, [w:] Antropologia kultury wizualnej.
Zagadnienia i wybór tekstów, red. I. Kurz, P. Kwiatkowska, Ł. Zaremba, Warszawa 2012. 
zmysłowej teorii kina jest zatem połączenie refleksji humanistycznej z perspektywą psychologiczną.

Strona formalna filmu nie prowokuje nas jedynie do procesów kognitywnych, nie tylko wywołuje w nas określone reakcje. Istotnym aspektem jest także to, że dzieło kinowe, jakby to ujął Slavoj Žižek[2], porusza naszą fantazję. Cielesna percepcja filmu może zawierać się już w samym oddziaływaniu środków filmowego wyrazu - czy to będzie montaż równoległy, kolor, kompozycja kadru, długość ujęcia, zaś w perspektywie technicznej - ważny będzie kąt, z jakiego operator filmuje scenę, ruch czy układ poszczególnych scen, zbliżenie i światło.

„Przestrzeń pozakadrowa jest domeną wyobraźni”[3] - to, co widzimy w filmie lub to, czego reżyser nam nie pokazuje, wiąże się z naszą wyobraźnią. Kiedy pewien obiekt zostaje przesunięty poza obręb kadru, nasza ciekawość się wzmaga. Czasami chcielibyśmy zobaczyć więcej, co wiąże się z pozycją podglądacza, jaką przyjmujemy w perspektywie filmowego dzieła, zaś, w świetle słów Laury Mulvey, kino to przyjemność patrzenia, zatem w ten sposób reżyser może manipulować naszymi oczekiwaniami i wyobraźnią, mieszając to wszystko ze sobą.

Zmysłowa teoria kina jest zanurzona w fenomenologii, czyli pojawia się swoista sprzeczność. Wrażenia odbioru filmu funkcjonują gdzieś pomiędzy intelektualną analizą a zawieszeniem sądów o rzeczywistości. Na granicy między zatopieniem się w filmowej rzeczywistości a świadomością technicznego wymiaru wykreowanych środków filmowego wyrazu. To wszystko ma wiele wspólnego ze sztuką operatorską Emmanuela Lubezkiego.

Obraz zatrzymuje się na mężczyźnie stojącym z kubkiem kawy pośród ludzi zmierzających w wielu kierunkach. Znajdujemy się w otoczeniu szarości i brudnych ulic, przechodnie zdają się pogrążeni w głębokiej melancholii. Przez kilka długich sekund razem z bohaterem kontemplujemy tę chwilę. Przerywa nam wybuch - słychać krzyki i odgłos kroków uciekających. Niemalże czuć ludzkie przerażenie czy dreszcze biegnące od krzyża aż po kark. Zapada ciemność i nie mamy dokąd uciec.

Ludzkie dzieci Alfonsa Cuaróna rozpoczynają się od głosu dobiegającego z dziennikarskiej audycji. Zanim zobaczymy wykreowaną rzeczywistość, słyszymy wzmianki o niej. Z ciemności wyłaniają się twarze ludzi przysłuchujących się wypowiedziom dziennikarzy - są zasępieni i przerażeni, ściskający w dłoniach kubki z niedopitą kawą, stłoczeni na niewielkiej przestrzeni. Na dalekim planie widać czerwony londyński autobus i ludzi zmierzających w różne strony. Przez tłum do kasy przeciska się główny bohater. Zamawia napój, a potem opuszcza kawiarnię, a my opuszczamy ją razem z nim. Śledzimy go zza pleców, przeciskamy się pomiędzy ludźmi, jesteśmy zanurzeni

[2] S. Žižek, Przekleństwo fantazji, przeł. A. Chmielewski, Wrocław 2001.

\section{Autorski wymiar przestrzeni}


w klaustrofobicznej, pełnej napięcia przestrzeni. Z ekspozycji otrzymujemy kluczowe informacje - dowiadujemy się, że zmarł najmłodszy człowiek na świecie, który miał osiemnaście lat - znaleźliśmy się w futurystycznej wizji, w rzeczywistości, w której od wielu lat nie urodziło się ani jedno dziecko.

Śledzimy bohatera pośród zgiełku ulicy, gdy zatrzymuje się na chwilę, aby do czarnej kawy dolać alkoholu - okrążamy jego postać, aż w końcu obraz staje się nieruchomy. Chwilę później w kawiarni, w której znajdowaliśmy się przed momentem, następuje wybuch. Dobrze, że nie używasz cukru i śmietanki, powie później przyjaciel Theo. Rozedrgany obraz przybliża nas do pomieszczenia pełnego kłębów dymu, słychać krzyki i dźwięki samochodowych alarmów, z lokalu wychyla się poraniona kobieta. Następuje gwałtowne cięcie, zapada ciemność, na ekranie pojawia się tytuł.

Akcja Ludzkich dzieci osadzona jest w posępnym, pogrążonym w chaosie świecie, w którym od wielu lat nie urodziło się ani jedno dziecko. Paleta barwna ujęć, sposób montażu i gra aktorska potęgują to wrażenie - trafiliśmy do rzeczywistości, w której nie ma już nadziei, a jedyne, co zostało, to coraz szybciej postępująca dezintegracja. Na dzieło Cuaróna możemy spojrzeć $\mathrm{z}$ wielu perspektyw: jak na dystopię, kino postapokaliptyczne, jak również na niezwykłą opowieść wizualno-formalną. Tak o konstrukcji świata Alfonsa Cuaróna pisze Adam Horowski:

Mimo że Wielka Brytania jako jedyny kraj jeszcze nie upadła, to oznaki fizycznego, społecznego i moralnego rozkładu widać na każdym kroku. Przy drogach leżą zwierzęce zwłoki, na polach palone są ciała zdechłych koni, rzeki i strumienie są martwe od zanieczyszczeń. Obywatele bezustannie padają ofiarą wojny domowej między faszystowskim rządem a rebeliantami z Fisher[4].

W wymiarze narracyjnym mamy zatem do czynienia $\mathrm{z}$ dystopią opowiadającą o zerwaniu ciągłości świata, w którym społeczeństwo rozpada się z powodu niemożliwości urodzenia dziecka. Analizując konstrukcję przestrzeni, warto zwrócić uwagę na kilka aspektów. Po pierwsze - początkowe sekwencje Ludzkich dzieci toczą się w zamkniętych pomieszczeniach. Stare hale i autobusy, mieszkania stanowią dla bohaterów synonim poczucia bezpieczeństwa, kiedy wszystko to, co dzieje się na zewnątrz, pozbawione jest jakiejkolwiek kontroli. Zamknięte przestrzenie stanowią rodzaj ostatniego bastionu dawnego świata, $\mathrm{z}$ drugiej strony - w oczywisty sposób są zaprzeczeniem wolności. Po drugie, interesującym zabiegiem formalnym może być sposób filmowania spotkania bohaterów granych przez Julianne Moore i Clive’a Owena. Zanim jeszcze poznajemy Julian, widzimy ją na zdjęciu - na fotografii jej i Theo towarzyszy dziecko. Razem z bohaterem zatrzymujemy wzrok na odbitce odrobinę dłużej - dostrzegając bohaterkę, gdy zdejmuje z głowy kominiarkę - mamy już przeświad- 
czenie, że jest ona ważną osobą w życiu głównego bohatera. Podczas pierwszego spotkania z Julian bohaterom towarzyszy intensywne, złote światło, które zdaje się padać zza pleców kobiety. To wydaje się dość prostym symbolem - światło, które wskazuje czy to na nadzieję, czy na niemal nieuchwytne szczęście. Z tego względu, że ów środek wyrazu zastosowano konsekwentnie na przestrzeni całego filmu - staje się to nienachalne, a subtelne. Złote światło pada również wiele ujęć później - na matkę - pierwszą kobietę od wielu lat, która zaszła w ciążę. W opozycji do pogrążonych w szarościach scen z początku filmu kadr stanowi swoisty punkt zwrotny w tej historii.

W kontekście sensualnego potencjału zdjęć filmowych wyjątkowa jest scena, która ma miejsce w jadącym samochodzie i cała nakręcona jest w jednym ujęciu. Na samym początku pojawia się pozytywny wydźwięk - możemy odczuć bliskość pomiędzy bohaterami. Niespodziewanie nastrój się zmienia; pojawia się mnóstwo ludzi atakujących bohaterkę graną przez Juliannie Moore, która wykrwawia się i umiera. Pod względem technicznym łatwo jest odczuć, jak skrupulatnie nakręcono tę scenę, w której operator w pewnym momencie wychodzi z samochodu, nie przerywając ujęcia. Ponieważ forma nie funkcjonuje w oderwaniu od treści, taka kreacja świata wzmaga intensywne wrażenie płynące $\mathrm{z}$ filmowego obrazu. W Ludzkich dzieciach pojawia się jeszcze jedno długie ujęcie, w którym chaos i krzyki zderzają się z techniką, podczas którego nie sposób zauważyć, że w nieokreślonym momencie krew zostaje starta $\mathrm{z}$ ekranu pomimo braku wyraźnych cięć montażowych.

Przywołana scena jest także jednym z najintensywniejszych emocjonalnie momentów Ludzkich dzieci. Przede wszystkim pojawia się zestawienie wielu uczuć - od ulotnej chwili radości, kiedy bohaterowie po prostu się bawią, tak jakby nie przebywali w pogrążonym w wojnie domowej świecie, ale jakby wybrali się na urokliwą samochodową wycieczkę, aż do przerażenia i rozpaczy. Nastrój sceny zmienia się gwałtownie, kiedy bohaterowie zostają zaatakowani, samochód przyspiesza, widzimy ogień i krew.

Tak o emocjonalnych reakcjach w kontekście zmysłowej teorii kina pisze Bogusław Skowronek:

Równocześnie podczas oglądania filmu każda pojawiająca się myśl ma jakiś odcień emocjonalny - jest przyjemna, przykra, podniecająca itp. Emocje te z powrotem oddziałują na umysł i ciało, powodując wydzielanie się odpowiednich hormonów, pocenie się, zaburzenia rytmu serca czy wreszcie zmiany wielkości źrenic. Nie na darmo, nazywając odpowiednie gatunki filmowe, odwoływano się dawniej do „cielesnych” reakcji i mówiono o „dreszczowcach” lub „wyciskaczach łez”[5].

W Ludzkich dzieciach mamy do czynienia wręcz z przeładowaniem emocji. Poród, pościg zrealizowany w jednym ujęciu przez sieć 
wąskich korytarzy, lęk o nowo narodzone dziecko - następują kolejno po sobie. Nie mamy ani chwili na wyciszenie emocji, przez co na sekwencje reagujemy fizycznym napięciem.

Film ma również fragmenty nakręcone w duchu poetyki kina dokumentalnego - kiedy bohaterowie w długich ujęciach wędrują po sieci wąskich korytarzy, a kamera śledzi ich zza pleców. Możemy wtedy odnieść wrażenie, że mamy do czynienia właśnie z kinem dokumentalnym. Zanim Theo odnajdzie kobietę i jej córeczkę, z oddali słyszy głos matki i płacz dziecka. Przestrzeń jest zatem jednocześnie wykreowana przez zabieg operatorski, jak i wyobrażona. W ten sposób w Ludzkich dzieciach zostaje połączona kreująca silne emocje strona formalna $\mathrm{z}$ poruszającą warstwą treściową. Twórcy bardzo zadbali o naturalistyczny charakter ujęć; wrażenie realności jest na tyle silne, iż w momencie projekcji nietrudno uwierzyć, że to dzieje się naprawdę.

Widz jest pozbawiony w kinie możliwości działania, aktywnego uczestnictwa, bez reszty absorbuje go uczestnictwo uczuciowe. Sprzyjają temu zarówno okoliczności zewnętrzne (ciemność, unieruchomienie, bierność, samotność w tłumie), jak i środki wyrazowe kina, wśród nich przede wszystkim ruch zbliżenie i montaż, a generalnie - realistyczny sposób przedstawiania, który pozwala na to, by widz zadomowił się w świecie ekranowym[6].

Istotne jest nie tylko to, w jaki sposób te sceny są nakręcone, ale też sama przestrzeń, po której błąkają się postaci. Tak o relacji architektury, przeżycia i filmowej przestrzeni pisze Marta Habdas:

Rozpoczęcie wędrówki „trajektorią” jest jednocześnie początkiem rozwinięcia narracji. Cała trasa to historia właściwa. Sjużetem są tu zarówno zmienne segmenty korytarza, jak i obrazy widziane zza oszklonych ścian. Poszczególne odcinki trasy zestawione są z sobą $\mathrm{w}$ „montażowy” sposób. Przejścia pomiędzy nimi traktować można jako cięcia, a sam fakt poruszania się po budynku sprawia, że percypowane są one w filmowy, sekwencyjny sposób. Zmienność koloru, światła, tekstury czy wymiaru wnętrz same w sobie nie tworzą jeszcze całościowej narracji, ale przywołują doświadczenie „filmowości”, nacechowując przestrzeń mobilnością (rytmika zmian) i emocjami (wielość wrażeń) [7].

W przestrzeń Ludzkich dzieci zostajemy wrzuceni. Za pomocą wskazanych wcześniej środków wyrazu twórcy sprawili, że możemy odnieść wrażenie przebywania razem $z$ bohaterami - w ujęciach śledzących czy w rozedrganym obrazie. W ten sposób my także przechodzimy kolejne kondygnacje, opuszczamy budynek i wychodzimy na zalane miękkim światłem podwórko, poznajemy pomieszczenia rozpadającego się budynku. Architektura może ewokować „filmowość, ale, co najważniejsze - pociąga za sobą intensywne przeżycia. Konstrukcja przestrzeni w Ludzkich dzieciach ma wydźwięk metaforyczny, a tak-

[6] Ibidem.
[7] M. Habdas, Przestrzeń jako film - architektura $w$ perspektywie badań nad audiowizualnościa, „Przegląd Kulturoznawczy" 2013, nr 3(17). 
że uwyraźnia filmowe wrażenia. Metaforyczny, ponieważ zamknięte przestrzenie nasycone są emocjami, po początkowym iluzorycznym bezpieczeństwie - chaos wpełza również do środka. Wychodząc na zewnątrz, opuszczamy cienką ochronę ścian, trafiając do jeszcze bardziej niebezpiecznego miejsca - ale taki może być koszt wolności. Intensyfikująca filmowe wrażenia, ponieważ to my musimy zrekonstruować przestrzeń za pomocą dźwięków dobiegających spoza obrębu kadru.

Ostatecznie bohaterka z małym dzieckiem znajduje się na otwartej przestrzeni w łódce na spokojnym morzu. Film kończy się klamrą - zapada ciemność, ale wciąż słyszymy krzyki dobiegające ze statku. Możemy odczuć to tak, jakbyśmy obejrzeli jedynie wycinek tej historii. Resztę konstruujemy sami. Ma to wiele wspólnego z kognitywną teorią filmu, w świetle której kreujemy własny obraz tego, co widzimy na ekranie. Odbiór filmowej przestrzeni łączy w sobie zatem to, co pokazali nam twórcy, $\mathrm{z}$ tym, co wyobraziliśmy sobie podług danych wizualnych i dźwiękowych.

W filmie Wielkie nadzieje (Great Expectations, reż. A. Cuarón, 1998) pojawia się istotny składnik pamięci widzów - w momencie przywoływania wspomnień o tym filmie ta scena wskazywana jest najczęściej - gdy dwójka dzieci w starym, wielkim domu całuje się przy fontannie. Początkowo obserwujemy ją w oddaleniu, potem następuje gwałtowne zbliżenie. Zmiana planów w istotny sposób manipuluje naszą uwagą - z różnej odległości zwracamy uwagę na inne rzeczy. Według koncepcji Gilles’a Deleuze’a[8] zbliżenie zawiesza indywidualizację, w pewien sposób upodabnia twarze do siebie, a my, widzowie, nie wiemy, kto patrzy. Co więcej, filmowa przestrzeń nie pozostaje w tym momencie bez znaczenia. Bohaterowie znajdują się w wielkim, starym domu, pełnym drobiazgów i zakamarków, mogącym stanowić synonim tajemnicy, ale też podkreślenie wyjątkowości dzieciństwa. Scena pocałunku pojawia się w Wielkich nadziejach dwukrotnie - za pierwszym razem bohaterowie są dziećmi, za drugim - powracają do tego samego miejsca już jako dorośli. Ujęcie stanowi zatem odbicie sceny z dzieciństwa - bohaterowie wspominają tamtą sytuację, zaś my - wspominamy ją razem $\mathrm{z}$ nimi.

Drzewo życia Terrence’a Malicka to film, w którym zdjęcia wychodzą na pierwszy plan. Pojawia się kreacja przestrzeni, pośród której bohaterowie wyraźnie się gubią, która jest większa od nich i która w dużej mierze stanowi ich odbicie postrzegania świata, w którym boski wymiar jest niezwykle istotny. Ma to miejsce ze względu na treść filmu bohaterowie są osobami wierzącymi i przestrzeń filmowa w pewien sposób oddaje charakter ich wiary. Z punktu widzenia bohaterów przestrzeń istotnie jest nieskończona. Ludzie gubią się pośród tej nieokreślonej przestrzeni, są mali i nieistotni w świecie wykreowanym przez twórcę.

[8] G. Deleuze, Kino 1. Obraz-ruch. 2. Obraz-czas, przeł. J. Margański, Gdańsk 2008.

\author{
Cielesna percepcja \\ konstruowania \\ filmowej przestrzeni
}


W filmie pojawia się wyraźne podkreślenie natury i miejsc, pośród których funkcjonują bohaterowie. Oglądamy je z ich perspektywy, odczytując za pomocą zdjęć ich emocje. W dziele Malicka pojawiają się na przykład ujęcia odwrócone do góry nogami, kiedy świat bohaterów drży w posadach, a my - upadamy razem $\mathrm{z}$ nimi. W tym filmie równie istotna jest kolorystyka, która oddaje zmienność nastrojów postaci i odbiór rzeczywistości - na świat spoglądamy ich oczami, przez pryzmat ich odczuć. Z drugiej strony, w filmie pojawiają się również ujęcia skoncentrowane na wspaniałości natury, trochę tak, jakby bohaterowie próbowali odnaleźć się pośród tego wszystkiego.

Gra światłem w obiektywie Emmanuela Lubezkiego często sprowadza naszą uwagę na rodzaj nadziei, w nierzadko posępnych światach wykreowanych przez twórców. W przypadku Ludzkich dzieci jest to postapokaliptyczny charakter rozpadającego się świata, w którym jednak dla głównego bohatera pojawia się nadzieja w postaci ukochanej z przeszłości, w Drzewie życia mamy do czynienia z matką, która straciła dziecko, ale nadzieję pokłada w Bogu.

Bliskie do sposobu sfilmowania świata w filmie Drzewo życia ukazanie przestrzeni pojawia się w Zjawie Iñárritu, w której gubi się bohater zagubiony w wędrówce. Kolorystyka, tonacja, a także przestrzeń zdają się oddawać zimno świata bohatera i to zarówno w dosłownym sensie, jak i w perspektywie nastroju panującego w tamtej rzeczywistości. Wizualna strona opowieści pokazuje walkę bohatera zarówno z samym sobą, jak i ze światem. Tutaj też pojawiają się długie ujęcia, które mogą intensyfikować nasz odbiór, od których nie możemy się oderwać i które możemy rozpatrywać zarówno ze względu na wymiar estetyczny, jak i kunszt techniczny autora. Ciekawym zabiegiem takiego sposobu filmowania są dwa sprzeczne uczucia pojawiające się jednocześnie. Z jednej strony, pojawia się wrażenie realności, zatapiamy się w stworzonym przez reżysera świecie. $Z$ drugiej - możemy docenić kunszt takich ujęć, głęboko odczuwając w ten sposób sztuczność rzeczywistości - czwarta ściana zostaje zatem zburzona.

W Birdmanie (reż. A.G. Iñárritu, 2014) przestrzeń ma odmienny charakter od sposobu filmowania zaproponowanego w Drzewie życia i Zjawie. W tym filmie odkrywamy razem z bohaterami nieotwartą przestrzeń, po której wędrujemy za postaciami. Może się zdawać, że zostaliśmy zamknięci razem $\mathrm{z}$ nimi w tej klaustrofobicznej sieci wąskich korytarzy, gdzie w pewnym punktach zatrzymujemy się i trafiamy do osobnych mikrorzeczywistości.

W kolejnych analizowanych filmach wyreżyserowanych przez różne osoby możemy dostrzec analogiczne składniki stylu Emmanuela Lubezkiego. W Birdmanie śledzimy bohaterów zza pleców, błąkając się wraz z nimi po przestrzeni teatru, co może przywoływać na myśl analogiczne długie ujęcia $\mathrm{z}$ filmu Ludzkie dzieci. Podobnie - w przypadku drugiego z filmów: w jednej ze scen nasza uwaga skierowana jest na prześwity światła na suficie. W Drzewie życia w trakcie pogrzebu wychodzimy poza przestrzeń, kierując się w stronę światła przesiane- 
go przez kolorowe witraże znajdujące się ponad głowami bohaterów. W dziele Malicka zwracamy się w kierunku Boga, w którym nadzieję pokłada matka zmarłego mężczyzny, u Cuaróna - światło może symbolizować nadzieję na zmianę pogrążonego w chaosie świata. Możliwość zmiany zawiera się jednak w konieczności wyjścia poza pozornie bezpieczną przestrzeń budynku na znacznie groźniejszy otwarty świat.

Dla sposobu filmowania przez Lubezkiego istotne są także wielokrotnie wspominane długie ujęcia. W dużej mierze intensyfikują nasz odbiór, wywołując zmysłową percepcję, a także - nie pozwalają oderwać wzroku od tego, co dzieje się na ekranie. Już sama sztuka operatorska pociąga za sobą sensualne wrażenia, a przecież dzieła filmowe to nie tylko forma, ale także treść. Taka sytuacja ma miejsce szczególnie w scenie walki w Zjawie, podczas której u widzów może pojawić się wyraźne odczucie skrupulatności sposobu, w jaki została ona nakręcona. Możemy docenić kunszt reżysera w tym samym momencie, gdy razem z bohaterem próbujemy się zorientować, z której strony nadciągają atakujący. Innym aspektem zdjęć filmowych wskazanego dzieła Iñárritu jest budowanie przestrzeni kadrów potęgujących zagubienie głównego bohatera. Najczęściej postać ukazywana jest w oddali pośród lasów przysypanych śniegiem. Zima determinuje również zimne kolory palety barwnej filmu - co potęguje w nas wrażenie zagubienia czy niepokoju. Filmy stają się w ten sposób skomplikowanymi układankami. Odbiór dzieł kinowych łączy w sobie oddziaływanie pojedynczych środków filmowego wyrazu, emocji płynących z fabuły, a może także wynikać ze świadomości sposobu, w jaki sztuczne światy powstały.

Analogiczna sytuacja ma miejsce w scenie śmierci Julian w filmie Ludzkie dzieci, kiedy operator w pewnym momencie wychodzi z samochodu, nie przerywając kręcenia. Może z tego wynikać, że zmysłowy odbiór filmu nie jest powiązany jednoznacznie z rodzajem „zatopienia w filmowym świecie” czy z „projekcją-identyfikacją”. Fizycznych wrażeń nie musi kreować jedynie unikalność historii, ale może wypływać już z samych środków filmowego wyrazu - z połączenia między techniką filmową a doświadczeniem estetycznym. Co więcej, możemy mieć świadomość tego, w jaki sposób kolejne sceny powstały i jakie mechanizmy pozwoliły na taki a nie inny filmowy efekt. Cielesna percepcja nie musi wiązać się zatem z zapomnieniem, iż mamy do czynienia z filmem, ale wiedza na temat konstruowania środków filmowego wyrazu i kinowych symulakrów może takie doświadczenie wzbogacać. Istotnym aspektem jest także to, że sensualność filmowego przekazu wiąże się z naszą wyobraźnią. W świetle tego, co pisała Laura U. Marks o haptycznym odbiorze, reagujemy na zapamiętane przez nas wcześniej wizualne bodźce [9]. Nie musimy również koniecznie ich zobaczyć, aby na nie zareagować, możemy fizycznie odebrać wydarzenia, które sobie wyobraziliśmy albo które zostały przywołane w sferze dźwiękowej.

[9] L.U. Marks, The Skin of the Film. Intercultural Cinema, Embodiment, and the Senses, Durham, London 2000. 
Przestrzeń filmowa składa się z wielu elementów. Kadr filmowy ukazuje nam pewien obręb świata bohaterów, ale również istotne jest to, co znajduje się w przestrzeni pozakadrowej. Możemy zapamiętać, co znajduje się poza obrębem najmniejszego wycinka filmowego dzieła, jeżeli kamera przesunie się wcześniej po większym fragmencie świata bohaterów. Drugą opcją jest samodzielna konstrukcja przestrzeni, za pomocą dźwięków docierających do nas spoza obrębu kadru.

Konstruowanie przestrzeni za pomocą dźwięku ma miejsce w przywoływanej już scenie z filmu Ludzkie dzieci. Kee zostaje porwana razem $\mathrm{z}$ dzieckiem i Theo traci $\mathrm{z}$ nimi kontakt. Chwilę przed ich odnalezieniem słyszymy płacz dziecka. Wyobrażona przestrzeń filmowa wyraźnie się powiększa. Z warstwy treściowej dzieła wiemy, że dziecko Kee jest jedynym, jakie możemy usłyszeć. Podobnie jak Theo, próbujemy wychwycić, z której strony dobiega płacz, odczuwamy też ulgę, że dziecku nic się nie stało. W tamtym momencie zatem w pewien sposób razem $z$ bohaterem wędrujemy po tej przestrzeni, a także dzielimy jego uczucia. Filmowy świat nie jest tutaj zamkniętą przestrzenią, ale twórcy zostawili dla nas rozmaite furtki, które mają wpływ na konstrukcję kinowej rzeczywistości. Na otwartość filmowego świata wskazują Alicja Helman i Andrzej Pitrus w Podstawach wiedzy o filmie.

Rama kadru funkcjonuje jednakże odmiennie niż rama obrazu malarskiego. Obraz sztalugowy zamknięty ramą jest ściśle odgraniczony od otaczającej nas przestrzeni, nic, co znajduje się poza ramą, nie może do niego należeć ani się z nim łączyć. Odgraniczenie obrazu filmowego od przestrzeni sali kinowej jest równie apodyktyczne, ale wzrok, wyobraźnia, uwaga widza kinowego są nieustannie kierowane poza ramę na wiele różnych sposobów. Przedstawianie i konstruowanie układów przestrzennych rzadko zachodzi $\mathrm{z}$ uwagi na ich samoistną wartość, najczęściej natomiast z uwagi na całokształt świata przedstawionego, fabułę i akcję[10].

Różnica pomiędzy odbiorem ramy kadru a ramy obrazu malarskiego tkwi zatem między innymi w naszym sposobie patrzenia na dany rodzaj obrazu w zależności od kontekstu. Istotny nacisk na to, w jaki sposób widzimy, położył Władysław Strzemiński. W swojej Teorii widzenia zwracał on uwagę na wiele mechanizmów związanych z percepcją rzeczywistości i dzieł sztuki. Nie sposób nie dodać, jak bardzo wyjątkowy jest fakt, iż pisząc swoje dzieło, artysta widział tylko na jedno oko.

Istnieje wzajemny wpływ myśli na widzenie i widzenia na myśl. Myśl stawia pytania, na które ma odpowiedzieć widzenie. Widzenie daje zasób materiału obserwacyjnego - i ten zasób ulega sprawdzeniu i uogólnieniu w procesie opracowania myślowego[11]

- takie ujęcie widzenia możemy postrzegać jako rodzaj perspektywy hermeneutycznej, w której na zasadzie koła hermeneutycznego nie możemy obserwować zjawisk bez obecnych w nas kontekstów i sądów na 
temat świata. Następnie według wskazówek poddajemy to, co widzimy, intelektualnej analizie. To, o czym pisał Strzemiński, łączy się zatem ze zmysłową teorią kina w kontekście połączenia odbioru bodźców wizualnych z naszymi wcześniejszymi doświadczeniami.

Wróćmy do płynnych granic ramy obrazu filmowego. Poza kadr przestrzeń wykracza aż na sześć różnych stron. Istotne jest, co się dzieje po lewej i prawej stronie kadru, powyżej i poniżej, ale także to, co się dzieje za bohaterami, a także przed, czyli w miejscu, gdzie film został nakręcony. Strefa znajdująca się przed obrębem kadru kieruje naszą uwagę w stronę kunsztu reżysera i operatora. W ten sposób cielesne wrażenia w filmie Ludzkie dzieci mogą wynikać ze świadomości tego, jak niełatwo było nakręcić tak skomplikowane ujęcia.

Wrażenie powiększonej przestrzeni za pomocą dźwięku wydaje się mieć miejsce jedynie w przypadku dźwięku diegetycznego. Muzyka ilustrująca spoza diegezy prowokuje zupełnie innego rodzaju doświadczenie - emocje mogą płynąć na przykład z samego estetycznego odbioru muzyki. Natomiast zwróćmy uwagę, że w Ludzkich dzieciach dźwięk niediegetyczny występuje rzadko. Ujęcie ucieczki Theo z Kee i dzieckiem opiera się tylko na dźwięku, który występuje w akcji - słyszymy kroki, uderzenia, strzały, ludzkie jęki. Żadna potencjalnie potęgująca emocje muzyka nie jest potrzebna, ponieważ nawet bez niej odnosimy wrażenie, że bohaterowie trafili do piekła.

We wskazanych przykładach możemy zatem dostrzec autorski styl operatora Emmanuela Lubezkiego. Kolejnymi elementami jego stylu są między innymi długie ujęcia, kadry projektowane w naturalnym oświetleniu, śledzenie bohaterów zza ich pleców czy wyjątkowe kształtowanie wyobrażonej przestrzeni wykraczającej poza obręb kadru. Prowokuje to sensualne wrażenia płynące już z samych zdjęć, chociażby na zasadzie momentu, w którym próbujemy zidentyfikować całość przestrzeni - nie tylko tej sfilmowanej, ale także całościowej przestrzeni, pośród której znajdują się bohaterowie.

Tandemy „reżyser-operator” nie są w świecie filmowym niczym niezwykłym. W przypadku Emmanuela Lubezkiego sytuacja jest jednak szczególnie interesująca ze względu na współpracę z kilkoma twórcami, których moglibyśmy określić jako autorów filmowych.

Warto zadać pytanie, na ile sztuka operatorska Emmanuela Lubezkiego może mieć wpływ na twórczość reżyserów-autorów, a także w jaki sposób odnieść te rozważania do koncepcji kina autorskiego. Charakterystyczne elementy stylu operatora - jak choćby długie ujęcia czy gra świateł - pojawiają się w wielu jego dziełach, ale podobne elementy stylu możemy odnaleźć u pozostałych reżyserów-autorów. Koncepcja kina autorskiego ma swoje źródło w rozważaniach twórców i teoretyków z nurtu francuskiej nowej fali i neorealizmu włoskiego. Można się zastanowić, w jaki sposób dziś funkcjonuje autor filmowy kiedyś reżyser to był Ten, kto nie ma prawa się skarżyć i kto odpowiada za wszelkie elementy filmowego dzieła. Autorem filmowym był także twórca, która zamiast piórem, pisze kamerą i jest to dla niego po prostu 
jeden ze środków wyrazu. Z drugiej strony, przypatrując się zdjęciom Lubezkiego, nie sposób nie zwrócić uwagi na autorski wymiar jego twórczości - nierzadko operator uznawany jest za równie ważnego twórcę jak sam reżyser. Nie sposób również zaprzeczyć współpracy, jaka ma miejsce pomiędzy operatorem a reżyserem oraz w jak dużej mierze pokazują wyżej analizowane przykłady, w przypadku sztuki operatorskiej Emmanuela Lubezkiego mamy do czynienia ze swoistym wpływem na styl zarówno operatora na reżyserów, jak i reżyserów na styl operatora.

W tym kontekście bliższa wydaje się koncepcja Astruca[12], w świetle której rzeczywiście kamera „staje się piórem”, za pomocą którego można kreować autorskie światy. Autorski wymiar omawianych w tym artykule dzieł, jak między innymi Ludzkich dzieci, Zjawy czy Drzewa życia, funkcjonuje gdzieś na styku stylu Emmanuela Lubezkiego i aspektów stylu reżyserów-autorów. Współpraca operatora i reżysera wykracza również poza wspólnie stworzone dzieła. Oczywistym aspektem takich relacji jest wzajemnie przenikanie się kolejnych aspektów stylistycznych. Ciekawy przykład stanowi najnowszy film wyreżyserowany przez Alfonsa Cuaróna, w którym autorem zdjęć jest sam reżyser. Roma (2018) wydaje się przesiąknięta nawiązaniami do operatorskiej twórczości Lubezkiego zarówno w sposobie konstruowania długich ujęć, jak i w poszczególnych kadrach. Współpraca może mieć zatem znamiona wyjątkowości, ewokując zmysłowe doznania wynikające z połączenia warstwy formalnej z warstwą treściową.

Astruc A., Narodziny nowej awangardy: kamera-pióro, [w:] Europejskie manifesty kina: od Matuszewskiego do Dogmy: antologia, red. A. Gwóźdź, Warszawa 2002

Baker M.J., The Tactile Eye: Touch and the cinematic experience, London 2009

Bellantoni P., Jeśli to fiolet, ktoś umrze. Teoria koloru w filmie, przeł. M. Dańczyszyn, Warszawa 2006

Benjamin W., Twórca jako wytwórca: eseje i rozważania, przeł. R. Reszke, Warszawa 2011

Crary J., Camera obscura i jej podmiot, przeł. M. Szcześniak, [w:] Antropologia kultury wizualnej. Zagadnienia i wybór tekstów, red. I. Kurz, P. Kwiatkowska, Ł. Zaremba, Warszawa 2012

Deleuze G., Kino 1. Obraz-ruch. 2. Obraz-czas, przeł. J. Margański, Gdańsk 2008

Habdas M., Przestrzeń jako film - architektura w perspektywie badań nad audiowizualnościa, „Przegląd Kulturoznawczy” 2013, nr 3(17)

Helman A., Pitrus A., Podstawy wiedzy o filmie, Gdańsk 2008

Horowski A., Leksykon filmów postapokaliptycznych, t. 1, Poznań 2017

Jarman D., Chroma: księga kolorów, przeł. P. Świerczek, Katowice 2017

Kognitywna teoria filmu. Antologia przekładów, red. J. Ostaszewski, Kraków 1999.

Lacan J., Anamorfoza i spojrzenie, przeł. W. Michera, [w:] Antropologia kultury wizualnej. Zagadnienia i wybór tekstów, red. I. Kurz, P. Kwiatkowska, Ł. Zaremba, Warszawa 2012

[12] A. Astruc, Narodziny nowej awangardy: kamera-pióro, [w:] Europejskie manifesty kina: od Matu- szewskiego do Dogmy: antologia, red. A. Gwóźdź, Warszawa 2002. 
Landsberg A., Pamięć protetyczna, przeł. M. Szewczyk, [w:] Antropologia kultury wizualnej. Zagadnienia i wybór tekstów, red. I. Kurz, P. Kwiatkowska, Ł. Zaremba, Warszawa 2012

Marks U.L., The Skin of the Film. Intercultural Cinema, Embodiment, and the Senses, Durham, London 2000

Morin E., Dusza kina, przeł. K. Eberhardt, [w:] Antropologia kultury wizualnej. Zagadnienia $i$ wybór tekstów, red. I Kurz, P. Kwiatkowska, Ł. Zaremba, Warszawa 2012

Mulvey L., Do utraty wzroku, przeł. J. Majmurek, red. K. Kuc, L. Thompson, Kraków 2010

Ostrowska E., Przestrzeń filmowa, Kraków 2000

Przylipiak M., Kino stylu zerowego, Gdańsk 1994

Skowronek B., Ciało, emocje, rozum - raz jeszcze o mechanizmach odbioru filmu, „Annales" 2017, nr 2

Sobchack V., Carnal Thoughts, London 2004

Sobchack V., Pieprzyć ciało/ przetrzymać tekst, czyli jak wyjść cało z tego stulecia, przeł. M. Szcześniak i Ł. Zaremba, [w:] Antropologia kultury wizualnej. Zagadnienia i wybór tekstów, red. I. Kurz, P. Kwiatkowska, Ł. Zaremba, Warszawa 2012

Stańczyk, M., Zmysłowa teoria kina. Vivian Sobchack i sensuous theory, „Ekrany” 2015, nr 3-4 (25-26).

Strzemiński W., Teoria widzenia, Łódź 2016

Truffaut F., Reżyser: ten, kto nie ma prawda się skarżyć, [w:] Europejskie manifesty kina: od Matuszewskiego do Dogmy: antologia, red. A Gwóźdź, Warszawa 2002

Žižek Slavoj, Przekleństwo fantazji, przeł. A. Chmielewski, Wrocław 2001 